\title{
UNVEILING THE CULTURAL IDENTITY OF PROSPECTIVE ENGLISH TEACHERS AT A PUBLIC UNIVERSITY IN BRAZIL
}

\author{
João Fábio Sanches Silva* \\ Lucia Maria de Assunção Barbosa**
}

\begin{abstract}
When dealing with cultural studies and foreign language teacher education, those involved in the process of learning and teaching are somehow bound to concepts and attitudes which may lead them to changes or (re)adaptations of some of their values, beliefs and behaviors. Among these possible changes, identity is called into question. In this sense, identity seems to be concealed by many veils which are gradually withdrawn by the moment the subject gets involved with contexts which may question her own agency and the investments made to be part of such new context, as those which can be observed in constant flux of changes in prospective English teachers in Brazil. Based on such assumption, this text aims to discuss in what ways the construction and expression of cultural identity of prospective English teachers from a public university in Brazil occurs. Most specifically, it searches for unveiling to what extent such cultural identity may lead them to reflect about their role as future language teachers as part of their education. Data suggest that cultural identity is a notion which may help future language teachers to become conscious of their multifaceted identity, which can emerge and be unveiled.
\end{abstract}

Key words: cultural identity; teacher education; English.

\section{Introduction}

The interest for issues related to the construction of identity arises in the international literature as an emerging area of investigation. According to Block (2007: 27), "identities are lifelong processes along which individuals negotiate new subject positions, and shape and are shaped by their sociohistories". The author states that identity has become a relevant issue of investigation because the references people have became somewhat dislocated, and reasons for this seem to be related to new subject positions assumed in diverse economic classes, gender, or even race (Block 2007).

Identity also refers to what Butler (2004: 31) calls "norms of recognition", that is, norms that allow an individual to be intelligible to others so that they can

\footnotetext{
* Prof. Dr. at Universidade Estadual de Mato Grosso do Sul (UEMS), e-mail: joaofabioss@ yahoo.com.br.
}

** Assoc. Prof. Dr. at Universidade de Brasília (UNB), e-mail: lubarbo@power.ufscar.br. 
ascribe to that person a particular identity. However, there are unequal power relations to deal with, such as economic, cultural and social capitals that both facilitate and constrain interactions with others in the different communities of practice within which individuals engage. From this perspective, finding a definition for identity has become a complex task. Reasons for this are probably related to differences between theoretical orientations and research traditions that may account for different ways of understanding the referred notion.

Norton (1997) uses the term identity to refer to how people understand their relationship to the world, how that relationship is constructed across time and space, and how people understand their possibilities for the future. She takes the position, following West (1992), that identity relates to desire - the desire for recognition, the desire for affiliation, and the desire for security and safety. Such desires, West asserts, cannot be separated from the distribution of material resources in society. That is, people who have access to a wide range of resources in a society will have access to power and privilege, which will in turn influence how they understand their relationship to the world and their possibilities for the future. In this respect, Norton believes that a person's identity will shift in accordance with changing social and economic relations (Norton 1997).

Holliday, Hyde and Kullman (2004) conceive of identity as the ways individuals define themselves, or want to be defined in the social contexts they are part of. For the authors, identity is multi-faceted and shifts constantly. Such diversity in the construction of identity is summarized in the different discourses individuals use in order to influence other people's perceptions of themselves. In addition, Bhabha (1994) characterizes identity as being unfixed and unstable. According to the author, identity is not constrained to an essence, since an individual does not assume one sole and specific identity. On the contrary, every individual assumes many and diverse identities, such as geographical, social, religious, just to name a few. Even so, all of them are contingent, that is, these identities are unstable and dependent of particular social contexts.

The previous definitions of the notion of identity suggest that the construct is a multi-layered phenomenon, and as Block argues, "prove to be very difficult to arrive at a strict definition that will be valid for very long" (2007: 187). Therefore, an increasing number of studies adopt the poststructuralist approach to the concept of identity and, for example, consider identity "the understanding of who the person is and thinks other people are" (Danielewics 2001), whereas others call for the notion of 'subjectivity', understood as "the conscious and unconscious thoughts and emotions of the individual, her sense of herself and her ways of understanding her relation to the world" (Weedon 1997: 32).

Such different perspectives in viewing identity may be related to somewhat different theoretical frameworks and research traditions. For example, Morgan (1997) adopts a sociological approach to his conception of identity; Schecter 
and Bayley (1997) opt for an anthropological approach to the analysis of identity construction; Duff and Uchida (1997) draw on sociocultural theories of identity to address differences between American and Japanese teachers; and Leung, Harris and Rampton (1997) work with theories of ethnicity as a way of understanding the extent to which schools in England were adapting to an increasingly bilingual and multilingual student population, just to mention a few.

The perspectives presented above suggest that there seems to be a collapse of boundaries between the social and cultural, which makes it possible to talk of identity as a sociocultural construct embedded in larger social processes, marked by relations of power that can be either coercive or collaborative (Norton 1997). Such sociocultural conception of identity conceives of the notion as dynamic and constantly changing across time and space, constructed and being constructed by language.

Based on the precedent assumptions, we can say that the notion of identity rests on three main characteristics. First, that identity is not a fixed, stable, unitary, and internally coherent phenomenon, but is multiple, shifting, and conflictual (Norton 2000; Weedon 1997). Second, identity is not context-free, but is crucially related to social, cultural, and political contexts (Duff, Uchida 1997). And third, identity is constructed, maintained, and negotiated to a significant extent through language and discourse (Lam 2000). In this sense, individuals are somewhat affected and influenced by the cultural contexts they are related to, and the construction of identity seems to stand out the subject positions assumed in the experiences lived within these contexts, such as those of prospective language teachers in the state of Mato Grosso do Sul, Brazil.

\section{Previous research in the field}

In reviews of the literature, many scholars cite Norton's work as pivotal in reframing debates on identity (e.g. Block 2007; Morgan, Clarke 2011; Ricento 2005) and it was in the context of such work, as Zuengler and Miller note (2006: 43), that identity was established as a research area "in its own right". Further, as Block (2007: 864) notes, a poststructuralist approach to identity "has become the approach of choice among those who seek to explore links between identity and language learning".

In addition to the assumptions mentioned above, poststructuralists also emphasize the mutually constitutive effect between language and identity. Weedon (1997), for instance, states that language is the place where actual and possible forms of social organization are defined and contested, and this may have an impact on the identity construction, since it is the place where subjectivity is constructed. 
As Weedon notes, it is through language that a person negotiates a sense of self within and across a range of contexts, and it is through language that the person gains access to - or is denied access to - powerful social networks that give her the opportunity to give voice to her own identity. In this perspective, there may be an articulation between power, identity, and resistance expressed in and through language (Norton 2006), in which language is the means through which experiences are organized and identities negotiated.

In accordance with the notions of language and identity presented, Norton (2010) makes the case that foreign language educators and researchers should be aware of examining the social, historical, and cultural contexts in which the foreign language learning and teaching occurs, and how those involved in this process negotiate and, if it is the case, resist the diverse positions these contexts may offer them.

The assumptions above suggest that there is an emphasis on the role of the subject when interacting with different contexts, such as that of foreign language teacher education, where the prospective language teacher is at the center of linguistic and cultural enquiry, and views culture not as a list of items, but rather as a process where meanings and perspectives are negotiated (Norton 2000). It is based on these premises that the relation between culture, language and identity may be constructed.

Culture, language and identity have become important areas of investigation in Applied Linguistics and one of the reasons for culture to have become so important seems to be related to a growing view of language that incorporates more social and cultural perspectives, which may suggest that learning a foreign language involves learning the culture(s) the language expresses (Silva, Gil 2012).

In this perspective, foreign language learning is not solely based on mastering the linguistic system of the target language, but rather on communicating effectively in the target culture (Byram, Morgan 1994). Based on the preceding assumption arises the idea that the teaching of a foreign language cannot be separated from the teaching of culture, and in turn, this learning of language and culture together can influence the identity construction of those who are learning it.

Furthermore, following Lo Bianco, Liddicoat and Crozet (1999), culture is not longer considered a separate skill but an inherent part of language, as if they were two sides of the same coin. Thus based on that metaphor, it is possible to adopt the notion of linguaculture (Attinasi and Friedrich as cited in Lo Bianco, Liddicoat, Crozet 1999) as the main characteristic of the intercultural approach which focuses not only on the target linguaculture, but also on the learner's first linguaculture. 
According to Risager (2010), the concept of linguaculture has primarily been developed by Michael Agar (1994). Agar has coined the term as a concept covering language plus culture, and he is especially interested in the variation of linguaculture in discourse, both among different native users of the same language, and among people who use the language as a native and/or as a foreign language. Risager (2010) explains that Agar focuses on the semantic and pragmatic irregularity of linguistic practice and invites the reader to explore 'rich points' in intercultural communication, i.e. points where communication is inaccurate.

Whereas Agar uses the concept of linguaculture in order to theorize on language and culture, Risager (1998) uses the term linguaculture as a concept that highlights the culturality of language while at the same time maintaining the conception of linguistic flows across cultural contexts in the world. For Risager (2010), it is possible to say that while languages spread in social networks, across cultural contexts and discourse communities, they still carry linguaculture with them.

In addition to what we stated above, if language and culture are inseparable, then as learners acquire a new language they will also be acquiring a new culture. However, we argue that such culture is not the same as either the learners' native culture or the culture of the language they are studying. That is, as learners become familiar with a foreign language they may come to understand other values and meanings to the foreign culture that are alien to their own culture (Baker 2003). Such understanding emphasizes the significance of individual interpretations of culture.

Such assumption suggests that individuals are shaped by their sociohistories but they also shape their sociohistories as life goes on. According to Block (2007), the entire process is conflictive as opposed to harmonious and individuals often feel ambivalent. The author still reminds us of the unequal power relations to deal with, around the different capitals that both facilitate and constrain interactions with others in the different communities of practice with which individuals engage in their lifetimes, which may impact their identity in construction (Block 2007).

\subsection{Research Questions}

Based on the premises above, this text aims to answer the following research questions: in what ways the construction and expression of cultural identity of prospective English teachers from a public university in Brazil occurs; and most specifically, to what extent such cultural identity may lead to reflections about their role as future language teachers. 


\section{Methods}

In order to answer the research questions presented above, a qualitative approach was used in the study which provided the means for writing this paper, in an attempt to "make sense of, or interpret, phenomena in terms of the meanings people bring to them" (Denzin, Lincoln 1998: 3). In relation to qualitative methods of conducting research, the study followed an "exploratory-interpretive paradigm which utilizes a non-experimental method, yields qualitative data, and provides an interpretive analysis of the data" (Nunan 1992: 4).

The participants of the study which provided data for this paper were undergraduate students of a language teacher education program at a public university in the middle-west of Brazil. The group of senior student-teachers comprised a total of 21 students. However, due to space constraints, only six participants, named as Doris, Ian, Pam, Christine, Jenny and Lucy, were selected for this paper. Their names have been changed to protect their identities.

We collected information during the second semester of 2011 by means of an open-ended questionnaire, a narrative production and semistructured interviews. At the end of the data generation process, there were 16 questionnaires, 15 narrative productions and 10 tape recorded interviews. The idea of using interconnected methods, or triangulation, reflects our desire to get a better understanding of the subject matter in question since "objective reality can never be captured" (Denzin, Lincoln 1998: 4). The instruments used for data generation are described next.

The data were examined and interpreted in light of the student-teachers' life stories and English learning experiences shared by them in the generation of data as well as with the support of prior theory on identity construction. Data generation was woven together in a narrative form with the purpose to illustrate and interpret the discursive construction of identity of these student-teachers.

\section{Data Analysis and Discussion of Findings}

As already referred, Norton considers identity a site of struggle, in a way that subjectivity is produced in a variety of social sites, all of them structured by relations of power in which the person assumes different subject positions (Norton 2000) at times contradictory, and such conflict in the cultural identity construction of the participants as future language teachers will be addressed in the present section. 


\subsection{The cultural identity of undergraduate students as a site of struggle}

Following in this subsection, we discuss the concept of identity as a site of struggle in a language teacher education undergraduate program*, addressing three main points, which are: first, the reasons that led the participants to attend the program; second, the reflections of such choice in their learning and/or using of the foreign language; and third, the impact of the choice on their future professional lives.

In relation to the reasons that led the participants to attend the program, Doris, one of our participants, explained that Letras was her first option in the entrance examination process, although the low number of candidates in such process had influenced her decision for attending it. Doris also mentioned that the program was an opportunity for an undergraduate education, and that it might contribute somewhat to her entrance in the public service field, something quite desirable in Brazil. For Doris, the degree in languages was not the direct goal of her pursuit in the program, but to obtain the university degree.

Differently, Ian declared that Letras was not his first option in the entrance examination process. His first choice for an undergraduate education was the Law program, but after failing to be approved two consecutive times in the entrance examination process, he decided to opt for Letras instead. In this respect, Lucchiari (1998) contends that there may be social influences in the kind of choices for a certain future profession, such as the lack of financial conditions to afford paying for a course, and afterwards, to start the career, and/or the lack of the necessary knowledge to be approved in the entrance examination process, for instance.

Differently from the previous two participants, Pam explained that her option for Letras was originally influenced by social factors. She mentioned that her parents could not afford paying for a private undergraduate education and she was supposed to choose a program which was located near her parents' home. In the interview, she complemented this thought by stating that being a teacher was also never part of her professional imaginary.

Notwithstanding the conflict experienced by Pam before starting the program, she was the only respondent in the group of student-teachers involved in the study to be effectively teaching. Pam used to teach English at a social assistance project as a volunteer once a week. She seemed to have a strong identification with the project, and contrary to her initial point of view about being a teacher, she identified with the profession, as she said that, "I really like it. I get quite

* In Brazil, the language teacher education undergraduate program is called Letras. 
anxious when the Saturdays are coming, because those are the days of the classes" (Pam, questionnaire, 2011).

In a somewhat different perspective from the previous participants, Christine mentioned that she chose Letras as her first and only option in the entrance examination process. However, Christine made it clear that her initial identification with the program was due to her inclination for Literature, saying that English has been given her as a 'curse in disguise' (Christine, questionnaire, 2011). Besides such apparent contradictory feeling, she claimed to have gotten used to studying English, and if she was offered a job opportunity as an English teacher, she would promptly accept it.

Jenny, somewhat similarly to Ian, explained that Journalism would be her first option in the entrance examination process, if she could afford a private university degree, but she decided for attending Letras in a public university instead. Such attitude suggests that some of the choices the student-teachers make are based on social circumstances and factors others than just their preference for a specific degree, which may impact the construction of their identity of future professionals in second-option programs.

Notwithstanding the conflictive choice between a previous desired undergraduate education and her current option, Jenny acknowledged her intention to become a language teacher, although learning English has always been a challenge for her. Jenny also highlighted the importance of studying a foreign language in her undergraduate program, since such knowledge would help her understand the mechanics of her own language. However, she believes that her education would have been much more productive if the program she attended had been offered not as a double-certification degree, but as a single one.

The stances taken by the participants in relation to their entrance Letras suggest that the choice of an undergraduate education is at times mediated by social factors which may lead to conflicts, such as Doris considering Letras program an opportunity for an undergraduate education, disregarding the teaching profession. Another example is evidenced by the imposition of Pam's parents, demanding from her either to be approved in a public university in the state near the city they used to live, or to get back to her parents' home to attend a program in a private undergraduate institution.

Ian and Jenny have also faced different sorts of conflicts when started the program. As already stated, Ian lacked the necessary symbolic capital to be approved in the entrance examination test for the Law school, which led him to opt for a second-option undergraduate degree. Similarly, Jenny also decided to take up a second-option degree in Letras, as she could not afford paying for a Journalism degree in a private institution. 
Christine and Lucy claimed to have opted for the Letras program as their first option as an undergraduate degree, but they have also experienced different forms of conflicts during their undergraduate education. Besides the need to quit attending the program because of her partner's occupation, Christine was also compelled to 'go through English' in order to achieve her goals with Literature; whereas Lucy was struggling with some of her classmates who did not seem to be quite concerned with their own education as she was (Lucy, questionnaire, 2011).

Besides all the social circumstances contended by the participants, learning and/or using English was not considered a reason for choosing Letras, which may position the participants in a cultural context that perhaps they were not willing to take part of, turning it to a site of struggle. We will explore such topic in the upcoming subsection.

\subsection{Learning and using English as a site of struggle}

Norton's definition of identity as 'a site of struggle' (1995) seems to be appropriate for the participants' experiences as learners and/or users of English, both before attending Letras, as well as while they were still undergraduate students, learning the language and the craft of being a teacher. Doris, for instance, started to learn English at a very young age, but this process of learning a foreign language was not free from conflicts. It was marked by social circumstances that forced her to change to different private language courses during the time she was studying the language, and also to exchange symbolic capital in order to achieve her goals with the language, such as teaching the language for children in exchange of the expanses with her own learning.

The identity of Doris as a learner/user of English was still conflictual when she considered the English native speaker the main reliable source of input for students of such language. Doris somewhat conditioned her learning of English to possible experiences of using the language with native English-speakers, highlighting her desire for such contact.

Somewhat similarly, Ian also faced the learning of English in the undergraduate program as a site of struggle. Although he brought with him a good deal of symbolic capital in relation to English, due to previous learning experiences, he recognized that learning English in Letras could be improved by means of "new language laboratories and more space in the syllabus for the English classes, besides more conversation practices" (Ian, questionnaire, 2011).

By mentioning that his English education could be somewhat improved if the language laboratory offered him better conditions to practice the language, Ian seemed to be aware that the practice in such context aimed to complement his education in relation to the development of speaking and listening skills, but 
the current conditions offered by the laboratory did not offer such possibility, which might prevent him from improving his symbolic capital in relation to the language practices.

It seems that Ian wished to have better communicative competence in English in order to improve his symbolic capital in relation to English, which could position him as a better professional in the area of teaching English. However, the feeling of being about to graduate from languages, and do not have the necessary communicative competence to be an English teacher seems to be restraining the emergence of the identity of a user of the target language, and consequently, of a future English teacher.

Similarly to Ian, who brought into the program a good deal of symbolic capital in relation to English, Pam also had a large number of English learning experiences before starting Letras. Some of these experiences highlighted her identity of a learner of English, although conflictual in nature, such as her English learning journey before starting her undergraduate education. The possibility of learning English in the program seemed initially to be an opposing starting point in relation to her previous learning experiences during her school days. According to Pam, she had always desired to take up a private English language course, but due to financial limitations she could never afford paying for one.

But something intriguing about this conflictive attitude in relation to the language is that she mentioned to feel quite comfortable when she used to speak English with some of her friends from abroad, but she felt very insecure when she was supposed to talk to her professors in the university. This apparent conflict in relation to using English with friends from abroad and the insecurity of using the language with professors in the university seems to have its bases in an imagined community aspired by Pam, the imagined community of teachers of English.

It seems that Pam recognizes her English professors as the particular members of the community she wishes to be part of. Norton (2006) believes that the people in whom learners have the greatest investment may be the very people who represent or provide access to the imagined community of a given learner, and this seems to be the case of Pam when she was expected to speak English with her professors in the university.

Similarly to the previous participants, Christine's identity of a learner of English was also a site of struggle. She mentioned in the questionnaire to have a relationship of 'tolerance' with the language, so that she could achieve her goals with Literature, while she would be learning a foreign language. Such attitude in relation to learning English seems to have its origin in unsuccessful learning experiences during high school, when she started to learn the language. 
Christine acknowledged the fact that at the beginning of her undergraduate education in Mato Grosso do Sul, she was very resistant to the idea of learning English, but now as a senior student, she could understand it much more easily, and she did not seem to despair anymore. According to Norton (2010), the concept of resistance is important when trying to understand the construction of identity, due to the fact that larger structural constraints and classroom practices may at times position learners in undesirable ways, and they can resist these positions in innovative and unexpected forms (Norton, 2010), and this seems the case of Christine, trying to reconcile her strong inclination for Literature and the learning of English in the program.

Similarly to Christine, learning English had been a challenge for Jenny since her childhood, when she had her first contact with the language. Her identity of a learner of English was a site of struggle at that time, especially as she perceived differences between the way she used to be taught English, and the new learning environment. Although the identity of a learner of English was at times a site of struggle for Jenny, learning the language did not seem to have negatively influenced the emergence of the identity of a user of the language, and the possibility of becoming an English teacher. Jenny also recognized that she has been improving the language little by little due to the practices in the undergraduate program.

The identities of undergraduate students and learners of English were experienced by the participants as a site of struggle, particularly due to social factors. Ian and Jenny, for instance, opted for an undergraduate program which was not their first choice; whereas Jenny and Pam could not attend private English courses because of financial limitations. Other circumstances also contributed to such conflictual process of identity work, such as the program's double-certification, recalled by Christine and Jenny.

The participants were also capable of discerning aspects of their education that could be improved, such as Ian requiring better conditions in the language laboratory, and Pam asking for more English classes in the syllabus of the program, which somewhat could impact their own learning of the language, providing them with better communicative competence, and consequently with their future professional lives as language teachers. In the upcoming subsection, we bring into discussion the conflictual construction of the identity of future language teachers.

\subsection{A site of struggle as future language teachers}

The construction of the identity of future language teachers was also experienced by the participants as a site of struggle, which highlights the notion of identity work as dynamic and constantly changing across time and space, constructed 
and being constructed by the experiences of the individual in different cultural contexts.

The reason that led Doris to opt for Letras was not her previous identification with the program itself, but the low number of candidates in the entrance examination process, as already stated. Becoming a teacher for Doris was a site of struggle, as she believed that, "teaching is very stressful and devalued" (Doris, questionnaire, 2011). Although becoming a teacher was not Doris's first option as her future professional option, she recognized that she had the necessary symbolic capital to be an English teacher due to the cultural capital she has acquired from her years of studying and practicing the language in the private language courses before attending Letras. It seems that Doris assumed such identification with the language on the one hand, but she did not share the same feeling in relation to the fact of becoming a teacher on the other.

The lack of teaching experience was pointed out by Ian as major source of conflict in relation to his identification with the profession. Despite having been through the English practicum experiences in the program, Ian mentioned that the lack of teaching experience in the area made him feel insecure in relation to his future professional life as a language teacher. Norton (2001) argues that second language learners have images of the communities in which they want to participate in the future, and one of the characteristics that Ian seems to have attributed to the members of the teachers' community is confidence, a characteristic he believes not to have developed so far.

Similarly to Ian, who described his feeling of insecurity in front of a classroom as the teacher, Pam also recognized her difficulties and conflicts in the teaching contexts she was involved with - the assistance project where she used to teach English and the reading project she developed to work with Literature. Although Pam initially demonstrated certain feelings of discomfort in relation to becoming a teacher, she seemed to have overcome such conflict and assumed the imagined identity of a competent and concerned teacher, to the extent of positively analyzing the outcomes of her initial teaching experiences.

Similarly to the desire of Ian and Pam of becoming confident teachers, Christine mentioned her conflictive feelings about graduating and starting to work full of enthusiasm and good intentions, yet soon after the start, facing a reality of discouraging salaries and badly-structured schools in Brazil. In the conflict between her imagined identity of a future teacher and the disappointing scenario she observed during some of her practicum experiences, Christine reflected on her own English teaching practices and came to the conclusion that these experiences made her feel secure enough to assume the identity of a future English teacher. Christine acknowledged the importance of the cultural capital she acquired from the experiences she had, both with her English practicum and with the private language course she took during her undergraduate education. 
The data analyzed so far suggest that being an undergraduate student, a learner/ user of a foreign language, and at times assuming the identity of a future teacher is not free from constraints, and that the conflicts experienced by the participants, together with their changing and sometimes contradictory subject positions all contribute to the construction of their identity, "in a diverse, contradictory, dynamic, multiple rather than unitary, decentered rather than centered process" (Norton Peirce 1995: 15).

A conceptualization of identity as multiple, non-unitary and dynamic leaves room for the view that individuals need not be locked forever in particular subject positions. Rather, from this perspective, although some cultural contexts and practices may have limited or constrained the opportunities for the participants to identify with some subject positions, such as civil servant/undergraduate student, lawyer/future language teacher, researcher/teacher, confident/insecure teachers, and learners/teachers, other contexts and practices may have offered them enhanced sets of possibilities for social interaction and human agency, which allowed them to aspire to other imagined identities, different from the ones they initially had.

\section{Key Findings}

The participants' references to their option for the Letras undergraduate program suggest that the choice of an undergraduate education is at times mediated by social circumstances, such as not being able to afford a private undergraduate education, which may lead to conflicts. Additionally, learning or using English was not even considered by the participants a reason for choosing the program, which might have led some of them to experience the construction of such identity as a site of struggle, especially in a social context that perhaps, they were not willing to take part of. Doris, for instance, invested in the program in the form of an opportunity of undergraduate education, which could help her to access the community of civil servants, imagined by her as a more financially secure and stable occupation than teaching could be.

The identity of a learner and user of English in the undergraduate program was, for most of the participants, a site of struggle. Christine, for instance, claimed to have a relationship of tolerance with the language, and Ian wished to have developed better communicative competence in the language during his undergraduate education. The construction of the identity of a language teacher was also conflictive for some of the participants, such as Ian and Pam who believed not to be prepared to face a classroom as full-time teachers, due to the lack of teaching experiences in the area.

Norton's definition of identity as a site of struggle seems to be appropriate for my participants, as an extension of the position that identity is multiple 
and contradictory. The data analyzed suggest that for the participants, the construction of their identity as undergraduate students, learners/users of a foreign language, and for most of them, future language teachers was not free from conflicts, and such sites of struggle, together with their changing and sometimes conflictive subject positions, such as private language course students and public school students, all contributed to the construction of their identity "in a diverse, dynamic, multiple rather than unitary, decentered rather than centered process" (Norton Peirce, 1995, p. 15).

The analysis of data also demonstrated that some cultural contexts and practices limited or constrained opportunities for the participants to identify with particular subject positions. Pam, for instance, expressed feelings of insecurity when she was expected to speak with one of her former professors in English, apparently the one she had the highest investment; whereas Jenny's identity of an English learner during her childhood was a site of struggle, due to the discrepancy between her knowledge of the language and that of the other students in class. Finally, Ian desired to participate in the community of speakers of English and future teachers, and expected his classmates to aspire to the same communities, although those imagined communities were not shared by them.

\section{Conclusion}

One of the assumptions of the present text is that identities are discursively constructed, and embedded within social practices and diverse cultural contexts. In this respect, Pavlenko and Blackledge (2004) suggest that each aspect of identity redefines and modifies all others, and since individuals often shift and adjust ways in which they identify and position themselves in distinct contexts, identities are best understood when approached in their entirety, rather than through consideration of a single aspect or subject position.

From this perspective, the student-teachers in the study seem to be constructing who they are and how they want to be known in the recount of their experiences as English learners and undergraduate students. They seem to be constructing their identities at the encounter of multiple conditions, such as different school environments, learning experiences, and investment in the language practices. The student-teachers' lived experiences with the language and teaching practices seem to have contributed to the construction of the identity of learners/users of English and for most of them as future teachers of the language.

\section{Implications}

Although the present study focused primarily on the identity construction of undergraduate language students, there are broader developments in the field of applied linguistics that suggest important pedagogical implications for the 
future. In a broader perspective, by assuming that the identity of the future language teacher is not just a personality variable but a socially and historically constructed relationship to both institutional and community practices, then it follows that teachers, professors, researchers and policy-makers should all be implicated in the range of identities available to such future professionals. In a more localized perspective, given the particular context of the present text, the awareness of the notions of investment, imagined communities and resistance, as illustrated by the analysis of data, may wider the literature around issues of identity, teacher identity or language learning.

\section{References:}

Agar 1994: Agar M. Language Shock. Understanding the Culture of Conversation. New York: William Morrow.

Bhabha 1994: Bhabha H. The Location of Culture. London: Routledge.

Baker 2003: Baker W. Should Culture be an Overt Component of EFL Instruction Outside of English Speaking Countries? - The Thai context. Asian EFL Journal (on-line).

Block 2003: Block D. The Social Turn in Second Language Acquisition. Washington: Georgetown University Press.

Block 2007: Block D. Second Language Identities. London, UK: Continuum.

Bourdieu 1977: Bourdieu P. The Economics of Linguistic Exchanges. - Social Science Information. 6, 645-668.

Bourdieu, Passeron 1977: Bourdieu P., J. Passeron. Reproduction in Education, Society, and Culture. London/Beverly Hills, CA: Sage Publications.

Butler 2004: Butler J. Undoing Gender. London: Routledge.

Byram, Morgan 1994: Byram M., C. Morgan. Developing a Theory of Language-andCulture Learning. - In: Byram M., C. Morgan (eds.). Teaching and Learning Language and Culture. Clevedon: Multilingual Matters. 4-40.

Danielewicz 2001: Danielewicz J. Teaching Selves: Identity, Pedagogy and Teacher Education. Albany: SUNY, New York, 2001.

Denzin, Lincoln 1998: Denzin N. K., Y. Lincoln (eds.). Collecting and Interpreting Qualitative Materials. Thousand Oaks: Sage Publications.

Duff, Uchida 1997: Duff P. A., Y. Uchida. The Negotiation of Teachers' Sociocultural Identities and Practices in Postsecondary EFL Classrooms. -TESOL Quarterly. vol. 31, 451-486.

Holliday, Hyde, Kullman 2004: Holliday A., Hyde M., J. Kullman. Intercultural Communication: An Advanced Resource Book. London: Routledge.

Kramsch 1993: Kramsch C. Context and Culture in Language Teaching. Oxford University Press, Oxford.

Lam 2000: Lam W. S. E. L2 Literacy and the Design of the Self: A Case Study of a Teenager Writing on the Internet. - TESOL Quarterly. 34 (3), 457-482.

Leung, Harris, Rampton 1997: Leung C., Harris R, B. Rampton. The Idealised Native Speaker, Reified Ethnicities and Classroom Realities. - TESOL Quarterly. vol. 31, n. 3, 543-560. 
Lo Bianco, Liddicoat, Crozet 1999: Lo Bianco J., Liddicoat A., C. Crozet. Striving for the Third Place - Intercultural Competence Through Language Education. Melbourne: Language Australia.

McKay, Wong 1996: McKay L., C. Wong. Multiple Discourses, Multiple Identities: Investment and Agency in Second-Language Learning Among Chinese Adolescent Immigrant Students. - Harvard Educational Review. vol. 66, n. 3, 577-608.

Morgan 1997: Morgan B. Identity and Intonation: Linking Dynamic Processes in an ESL Classroom. - TESOL Quarterly. 31(3), 431-450.

Morgan 2007: Morgan B. Poststructuralism and Applied Linguistics: Complementary Approaches to Identity and Culture in ELT. - In: Cummins J., C. Davison (eds.). International Handbook of English Language Teaching. New York: Springer. 10331052.

Morgan, Clarke 2011: Morgan B., M. Clarke. Identity in Second Language Teaching and Learning. - In: Hinkel E. (ed.). Handbook of Research in Second Language Teaching and Learning. vol. 2. New York, NY: Routledge. 817-836.

Norton 1995: Norton P. B. Social Identity, Investment, and Language Learning. - TESOL Quarterly. 29, 9-31.

Norton 1997: Norton B. Language, Identity and the Ownership of English. - TESOL Quarterly. v. 31, n. 3, 409-429.

Norton 2000: Norton B. Identity and Language Learning: Gender, Ethnicity and Educational Change. Harlow: Pearson Education.

Norton 2006: Norton B. Identity as a Sociocultural Construct in Second Language Education. - In: Cadman K., K. O'regan (eds.). TESOL in Context. 22-33.

Norton 2010: Norton B. Language and Identity. - In: Hornberger N., S. McKay (eds.). Sociolinguistics and Language Education. Clevedon, UK: Multilingual Matters, 349369.

Norton 2011: Norton B. Identity. - In: Simpson J. (ed.). The Routledge Handbook of Applied Linguistics. New York/London: Routledge. 318-330

Norton, Toohey 2001: Norton B., K. Toohey. Changing Perspectives on Good Language Learners. - TESOL Quarterly. 35(2), 307-322.

Norton, Toohey 2011: Norton B., K. Toohey. Identity, Language Learning, and Social Change. - Language Teaching. 44, 4, 412-446.

Nunan 1992: Nunan D. Research Methods in Language Learning. Cambridge: Cambridge University Press.

Pavlenko, Blackledge 2004: Pavlenko A., A. Blackledge (eds.). Negotiation of Identities in Multilingual Contexts. Clevedon, UK: Multilingual Matters.

Ricento 2005: Ricento T. Considerations of Identity in L2 Learning. - In: Hinkel E. (ed.). Handbook of Research on Second Language Teaching and Learning. Lawrence Erlbaum Associates, Mahwah, NJ.

Risager 1998: Risager K. Language Teaching and the Process of European Integration. - In: Byram M., M. Fleming (eds.). Language Learning in Intercultural Perspective. Approaches Through Drama and Ethnography. Cambridge: Cambridge University Press, 1998. 242-254.

Risager 2010: Risager K. The Language Teacher Facing Transnationality. - Conferência no EUNoM Symposium. Friul, Italy. 
Schecter, Bayley 1997: Schecter S. R., R. Bayley. Language Socialization Practices and Cultural Identity: Case Studies of Mexican Descent Families in California and Texas. TESOL Quarterly. 31, 513-542.

Silva 2010: Silva J. F. S. Narrative Inquiries. - Unpublished Qualifying Examination. Universidade Federal de Santa Catarina, Florianópolis, SC.

Silva, Gil 2012: Silva J. S. F., G. Gil. Culture, Language and Identity Construction in Foreign Language Learning and Teaching: a Theoretical Discussion. - Contexturas. no. 19, 2012, 91-108.

Weedon 1997: Weedon C. Feminist Practice and Poststructuralist Theory. 2nd ed. Oxford: Blackwell.

West 1992: West C. A Matter of Life and Death. October, 61, 20-23.

Zuengler, Miller 2006: Zuengler J., E. Miller. Cognitive and Sociocultural Perspectives: Two Parallel SLA Worlds? - TESOL Quarterly. 40.1, 35-58. 